\title{
CUSTOMERS' DECISION TO SAVE ON THE GOVERNMENT BANK: A CASE STUDY IN INDONESIA
}

\author{
Zulher \\ Bangkinang Institute of Economic Science, Indonesia \\ Ratnasih Cicih \\ Borobudur University, Indonesia \\ *E-mail: h.zulher@gmail.com
}

\begin{abstract}
This study aimed to put forward the determination of the customer's decision to save the government banks. This study has been able to construct a theoretical model of the values contained in the quality of services and promotions in relation to the corporate image and the customer's decision to save. The results of the theoretical model explain that the values embodied in the quality of services and promotions directly affect the customer's decision to save and indirectly through the company's image influences customer's decision to save. This study confirms the concept that corporate image affects the customer's decision to save. At the same time, the results of this study also revealed the importance of a bank to have a good quality service and conduct good promotional activities to customers to enhance the corporate image that will have an effect on improving the customer's decision to save in a banking company. In an effort to improve a customer's decision to save in all government bank branch officesthen employees should often make contact with customers such as giving notification of the latest promotions, the latest savings products and rising interest rates, so that it can increase the customer's decision to save.
\end{abstract}

\section{KEY WORDS}

Quality of service, promotions, corporate image, customer decision, direct relationship, indirect relationships.

Bank is a financial institution that plays an important role in the economy of a country. The more developed the banking industry, the better the country's economic growth. According to Laws No. 10 Year 1998 on Banking, "Bank is an entity that collects funds from the public in the form of savings and provides them to the public in the form of loans or other forms in order to improve the standard of living of the people".

The development of banking in Indonesia is quite rapid, it is characterized by the large number of banks and increasingly broad bank reach, even reaching areas that are somewhat distant from the urban areas. This requires banks to be more sensitive to the needs of its customers because the customer is the source of bank profits. The benefits acquired by banks one of which comes from the number of bank deposits. Funds owned by the bank will be used to finance the real sector through lending and the bank will benefit from funds channeled to the public in the form of interest.

State Bank is a government-owned bank in Indonesia with a $56.75 \%$ shareholding owned by the Republic of Indonesia and 43.25\% shareholding owned by private in 2017 . State Bank was established on December 16, 1968 and is the first government-owned bank in Indonesia currently has 10,662 work units throughout Indonesia and abroad. State Bank branch offices are one unit under the guidance of State Bank branch offices throughout Indonesia, which has the ability to compete with otherbigger private banks.

The number of customer accounts is a factor of the number of customers who decide to save at a bank, the more the number of customer accounts, the more customers make transactions at the bank, one of which is a savings transaction. 
Table 1 - Number of State Bank Customer Accounts 2012-2016

\begin{tabular}{|c|c|c|c|c|c|c|}
\hline \multirow{2}{*}{ No. } & \multirow{2}{*}{ Year } & \multicolumn{5}{|c|}{ Product } \\
\cline { 3 - 7 } & & Deposit & Giro & Savings & Amount & Growth \\
\hline 1 & 2012 & 27 & 23 & 900 & 950 & - \\
\hline 2 & 2013 & 34 & 28 & 1,185 & 1,247 & $31.26 \%$ \\
\hline 3 & 2014 & 65 & 51 & 3,488 & 3,604 & $189.1 \%$ \\
\hline 4 & 2015 & 58 & 64 & 2463 & 2,590 & $-28.13 \%$ \\
\hline 5 & 2016 & 71 & 54 & 2,657 & 2,782 & $7,41 \%$ \\
\hline
\end{tabular}

Source: Bank Indonesia.

From Table 1 it appears that in 2013 the number of customer accounts increased from the year 2012 amounted to $31.26 \%$ with total accounts for 1,247, and then in 2014 the number of customer accounts experienced a high rise in the last five years in the amount of $18.91 \%$ with total accounts for 3,604. In 2015 the number of accounts has decreased by $28.13 \%$ with the number of accounts for 2,590 , this is due to the closure of accounts which resulted in decreasing number of accounts. In 2016, the number of customer accounts increased, but the increase is not too high compared to previous years in the amount of $7.41 \%$. According to data on the number of customer accounts that fluctuate each year, this can affect the amount of deposits in Government Banks in all sub-branch offices.

The quality of customer service isa factor that can increase a client's decision to keep savings in banks. Good quality of service of the banking system will affect the behavior of customers to stay with the bank and vice versa if thequality of service is poor, the customer will move to other private banks.

State Banks with excellent programs, as an example one of which is Untung Beliung which is an annual program of State Banks with attractive prizes, is certainly able to increase customers' decision to save. But this program is only intended for customers with large deposit which result in loss of customer decisions to increase saving activities.

Promotions by banks do not always have a good impact on banks. Promotions that are excessive persuasion can cause criticism from certain people who feel used and mocked. In addition, media selection and promotion targets also need to be considered because mistakes in the selection of media and promotional targets can have an adverse impact on state-owned banks such as waste of costs without any positive return on banks.

Various promotional activities carried out by the State Bank, with all supporting branch offices on the sale of funding products which funds are collected from the public in the form of savings, deposits and giro. In this case in accordance with one of the objectives of the promotion is to introduce the products produced that have advantages so that the products produced will be better known by the public. With the existence of these promotional activities, it cannot be separated from the costs incurred, namely the cost of promotion. The more limited the available budget, the narrower the space for companies to choose their promotion media. Conversely, the greater the available budget, the freer the company to choose the promotion method that is considered the most profitable.

\section{TEORETICAL REVIEW}

According to Shirley Harrison (2007: 61), corporate image is an impression, a feeling, an overview of the public against the company. Deliberately created impression of an object, person or organization. Ratih in Laura Tjokrowibowo (2013: 150), defines the customer's corporate image as acustomers' thinking about the image or the overall view of the service providers based on experience and understanding of each other's customers, both with regard to its services or the level of reputation and credibility achieved by the company according to the customer's perception.

Quality of service is the expected level of excellence and control over the level of excellence to meet the level of customer desires. If the services received or perceived (perceived service) as expected, then the quality of service or perceived service is good and 
satisfactory. If the perceived services exceed customer expectations, the quality of perceived service stated as an ideal quality. Conversely services received are lower than expected, and then the quality of service or perceived service is bad.

Meanwhile, according to Prasetyo and Miftahul in Juni Novalina Sirait (2016: 345), quality of service is the company's ability to meet the expectations of customers and also, if the service received or perceived already as expected, then the perceived quality is good and can satisfy the customer. Conversely, if the received lower than expected, the quality of the perceived poor or unsatisfactory.

The next definition according to Parasuraman in Lupiyoadi (2008: 180), Quality of service is a measure of overall assessment of the level of a good service, quality of service as a result of the perception of the results of a comparison between customer expectations with the actual performance of service. According to Kotler and Armstrong (2012: 62), Promotion is an element that is used to inform and persuade markets about new products or services to companies through advertising, personal sales, sales promotions, and publications. Tjiptono (2011: 219), defines promotion as a marketing activity that seeks to spread information, influence / persuade, or remind target markets for companies to be willing to accept, buy and be loyal to the model offered by the company concerned.

The next definition comes fromBasu Swastha (2009: 237), the promotion is the flow of information or persuasion in one direction that are made to direct someone or an organization to act to create the exchange in marketing. Meanwhile, according to Laksana (2008: 133), Promotion is a communication from the seller and buyer are derived from the exact information that aims to change attitudes and behavior of the buyer, who was not familiar become familiar with so that it becomes a buyer and still recall the product. According Tjiptono (2011: 59), quality of service is the expected level of excellence and control over the level of excellence to meet the level of customer desires.

If the services received or perceived (perceived service) as expected, then the quality of service is good and satisfactory. If the perceived service exceeds customer expectations, the quality of service takes as an ideal quality. Conversely, services that received lower than expected, the quality perceived bad service. The company's image according to Siswanto Sutojo (2009: 3) is the result of the perception about a group of people who form an organization and provide a service, which the perception can affect, quality of service evaluation either directly or indirectly.

Fanny and Seno Andrew in his research in 2015 with the title "The Effect of the Quality of Service towards the Corporate Image (Hospital Case Study)". Stating that quality of service has positive influence on the company's image. Thus, it can be a hypothesis that quality of service has a direct positive influence on the image of the company.

According to Kotler and Armstrong (2012: 62), Promotion is an element that is used to inform and persuade the market of a new product or service in the company through advertising, personal selling, sales promotion, and publicity. Shirley Harrison (2007: 61), defines the corporate image as an impression, a feeling, an overview of the public against the company. The impression that deliberately created of an object, person or organization.

Emny Oktavianty Tampubolon in her study of year 2015, declare that promotion have a significant effect on the company's image. Quality of service is the ability of the Company to meet the expectations of customers and also, if the service received or perceived already as expected, then the perceived quality is good and can satisfy the customer. Conversely, if the received service lower than expected, the quality of the perceivedservice is poor or unsatisfactory. Tri Astuti (2013: 186), states that the customer's decision to save is a decision taken on the customers by themselves to use the products or services of a bank or save of their money in banks with a specific purpose.

According Tjiptono (2011: 219), promotion is a marketing activity that seeks to spread informationinfluence/persuade, or remind the target market of the company to be willing to accept, purchase and be loyal to the housing models offered by the company concerned. Estri Juwanita (2015: 4), defines the customer's decision to save the final selection of a person or entity to store or place their funds in banks in the form of saving, deposits, and giro under the agreement between the bank and the customer.Rudy Haryanto and Hotman 
Panjaitan in their research on 2015 , states that the quality of service has a positive and significant impact on customer decisions to save through the image bank.

According to Laksana (2008: 133), Promotion is a communication from the seller and buyer which are derived from the exact information that aims to change attitudes and behavior of the buyer, from those who were not familiar become familiar so that it becomes a buyer and still remember the product. The company's image according to Siswanto Sutojo (2009: 3), is the result of the perception about a group of people who form an organization and provide a service, which perception can affect the evaluation ofquality of service either directly or indirectly.

\section{METHODS OF RESEARCH}

This research used path analysis method, looking for direct and indirect relationships. The study begins from August to December 2017. The stages of the research are as follows.

Planning/preparation phase of research done by selecting the problems that occur around where the the authors works which are in some sub-branches of the State Bank. Preliminary studies carried out on previous research to find theories. Furthermore, researchers create a research design that includes among others the formulation and problem definition, variable research which are the quality of service, promotion, corporate image and the customer's decision to save. And also to formulate hypotheses, research foundation, literature review, determine the sample and its research methods and data collection instruments used.

In questionnaires (questionnaire), researchers went directly to the respondents and informants have been set.

Sugiyono (2010: 115) suggests that the population is a generalize region consist of the object/subject that has certain qualities and characteristics defined by the researchers to learn and then drawn conclusions. The population in this study was all customers of State Bank and branch offices that have a save account (giro, savings and deposits) as many as 2,782 customers in 2016.

The samples, according to Sugiyono (2010: 116), are part of the number and characteristics possessed by this population. Sampling of customer of the State Bank Branch Office saves. To determine the sample of the population from a known number of populations, researchers use the Slovinformula.

Classical Assumption Test isa testto measure whether there is any indication ofdata deviation through distribution results, correlation, variance in the indicators of variables. Classic assumption test includes testingnormality, multicollinearity test, and autocorrelation and heteroscedasticity test. In this study autocorrelation test was not used because the obseverd data is not sequential all the time and are not related. The tests are as follows:

Normality test used to determine whether the data population has normal distribution or not (Priyatno, 2008: 28). Normality test can use two methods: LilieforsMethod and Kolmogorov-Smirnov Z Method.

This test aims to detect the presence or absence of multicollinearity; we can use the method of Tolerance value and VIF value. The aim of multicolinearity test is to test whether in the regression model have a correlation between the independent variables.

Heteroscedasticity test is used to find out whether or not there is a deviation of classical assumptions for heteroscedasticity. The prerequisite that must be fulfilled in the regression model is the absence of heteroscedasticity symptoms. Test methods for the heteroscedasticity test used include the Park Test, Glesjer Test, Spearman's Test and see scatter plot chart patterns.

Hypothesis test in this research is based on the purpose of research, with a $95 \%$ confidence level so that the level of precision or inaccuracies limit (alpha) of $5 \%$ or 0.05 . The basis of the test this hypothesis is:

- $\mathrm{Sig} \geq 0.05$ then Ho is accepted, Ha rejected;

- Sig $\leq 0.05$ then Ho is rejected, Ha accepted. 
Based on the study title of "Determinant of Customer's saving Decision on State Bank (Case in Indonesia)", it can be determined that:

$\mathrm{X}_{1}=$ Quality of Service;

$\mathrm{X}_{2}=$ Promotion;

$\mathrm{Y}=$ Corporate Image;

$\mathrm{Z}=$ Decision Customer Savings.

\section{RESULTS OF STUDY}

Regression Testing Results for Sub-Structure 1:

- Table 2 - T-Test for Sub-Structure 1

Coefficients $^{a}$

\begin{tabular}{|c|c|c|c|c|c|}
\hline \multirow[t]{2}{*}{ Model } & \multicolumn{2}{|c|}{$\begin{array}{c}\text { Unstandardized } \\
\text { Coefficients }\end{array}$} & $\begin{array}{c}\text { Standardized } \\
\text { Coefficients }\end{array}$ & \multirow[t]{2}{*}{$\mathrm{t}$} & \multirow[t]{2}{*}{ Sig. } \\
\hline & $B$ & Std. Error & Beta & & \\
\hline (Constant) & 4.827 & 2.408 & & 2.004 & .000 \\
\hline Kualitas Pelayanan & .473 & .081 & .491 & 5.843 & .000 \\
\hline Promosi & .403 & .087 & .391 & 4.649 & .000 \\
\hline
\end{tabular}

a. Dependent Variable: Corporate Image. Source: The test results SPSS 23 (2017).

The interpretation of T-Test results of Sub-Structure 1:

- Quality of service has direct effect individually (partial) or T-test on Corporate Image of State Banks and Sub-Branch Offices. In Table 2, shows the individual(partial) test or T-test get a Sig value of 0.000 , where the Sig value of 0.000 is smaller than 0.05 or $[0.000<0.05]$, then $\mathrm{Ho}$ is rejected and $\mathrm{Ha}$ is accepted, meaning the path analysis coefficient is significant. So, Quality of service has a significant effect on Corporate Image;

- Promotion has a direct effect individually (partial) or T-test on State Bank and Branch office Corporate image. In Table 2 shows the individual (partial) test or T-test get a Sig value of 0.000 , where the Sig 0.000 less than 0.05 or [0000<0:05], then Ho is rejected and $\mathrm{Ha}$ accepted means of path analysis coefficient is significant. So, Promotions significantly affect the Corporate Image.

Table 3 - T-Test Sub-Structure 2

Coefficients $^{\mathrm{a}}$

\begin{tabular}{|c|c|c|c|c|c|c|}
\hline \multicolumn{2}{|c|}{ Model } & \multicolumn{2}{|c|}{ Unstandardized Coefficients } & \multirow{2}{*}{$\begin{array}{c}\begin{array}{r}\text { Standardized } \\
\text { Coefficients }\end{array} \\
\text { Beta }\end{array}$} & \multirow{2}{*}{$\mathrm{t}$} & \multirow{2}{*}{ Sig } \\
\hline & & B & Std. Error & & & \\
\hline 1 & (Constant) & 3.193 & 2.135 & & 1.495 & .000 \\
\hline & Quality & .293 & .082 & .316 & 3.567 & .000 \\
\hline & Promotion & .277 & .084 & .279 & 3.311 & .000 \\
\hline & Citra Perusahaan & .330 & .090 & .344 & 3.690 & .000 \\
\hline
\end{tabular}

a. Dependent Variable: Customer Decision to save. Source: The test results SPSS 23 (2017).

The interpretation of T-test results of Sub-Structure 2:

- Quality of service has direct effect individually (partial) or T-test on Customer Decision to saveon State Banks and Sub-Branch Offices. In Table 3 shows the individual (partial)or T-test get a Sig value of 0.000 , where the Sig value of 0.000 is smaller than $0.05[0.000<0.05]$, then $\mathrm{Ho}$ is rejected and Ha is accepted, meaningthe 
path analysis coefficient is significant. So, Quality of service significantly affects the Customer Decision to save;

- Promotion has a direct effect individually (partial) or T-test on Customers decision to Save on State Bank and Branch office. In Table 3 shows the individual (partial) test or T-test get a Sig value of 0.000 , where the Sig 0.000 less than 0.05 or [0000<0:05], then $\mathrm{Ho}$ is rejected and $\mathrm{Ha}$ accepted means of path analysis coefficient is significant. So, Promotions significantly affect the Customer's Decision to Save.

Correlation analysis is used to measure the strength of the relationship between two or more variables. Here are the results of correlation analysis of quality of service, promotion, corporate image and save the customer's decision variables.

Table 4 - Analysis Results of Correlation in Determinants Variable Customers Decision to Save. Correlations

\begin{tabular}{|c|c|c|c|c|c|}
\hline \multicolumn{2}{|l|}{$n / n$} & Quality of Service & Promotion & Corporate Image & Customers' Decision to Save \\
\hline Quality of Service & $\begin{array}{c}\text { Pearson } \\
\text { Correlation } \\
\text { Sig. (2-tailed) } \\
\mathrm{N}\end{array}$ & 1 & $\begin{array}{c}.702 \\
\\
.000 \\
97 \\
\end{array}$ & $\begin{array}{c}.765^{*} \\
\\
.000 \\
97 \\
\end{array}$ & $\begin{array}{c}.775^{* \prime} \\
\\
.000 \\
97 \\
\end{array}$ \\
\hline Promotion & $\begin{array}{c}\text { Pearson } \\
\text { Correlation } \\
\text { Sig. (2-tailed) } \\
\mathrm{N}\end{array}$ & $\begin{array}{c}.702 " \\
.000 \\
97\end{array}$ & 97 & $\begin{array}{c}.735^{\circ 1} \\
.000 \\
97\end{array}$ & $\begin{array}{l}.754 " \\
.000 \\
97\end{array}$ \\
\hline Corporate Image & $\begin{array}{c}\text { Pearson } \\
\text { Correlation } \\
\text { Sig. (2-tailed) } \\
N\end{array}$ & $\begin{array}{c}.765^{\mathrm{x}} \\
.000 \\
97\end{array}$ & $\begin{array}{c}.735^{\circ \prime} \\
\\
.000 \\
97\end{array}$ & 1 & $\begin{array}{c}.791^{\prime \prime} \\
.000 \\
97\end{array}$ \\
\hline Customer's decision to save & $\begin{array}{c}\text { Pearson } \\
\text { Correlation } \\
\text { Sig. (2-tailed) } \\
N\end{array}$ & $\begin{array}{c}.775 \\
.000 \\
97\end{array}$ & $\begin{array}{c}.754 \\
.000 \\
97\end{array}$ & $\begin{array}{c}.791 \\
.000 \\
97\end{array}$ & 97 \\
\hline
\end{tabular}

** Correlation is significant at the 0.01 level (2-tailed). Source: The test results SPSS 23 (2017).

In Table 4 the results of the correlation analysis between quality of service, promotion, corporate image and customer savings decisions using guidelines from Sugiyono (2010: 214) shows a significant relationship with the respective correlation values of 0.775 (strong category), 0.754 (strong category), 0.791 (strong category).

\section{CONCLUSION}

The results show that the quality of service has a significant and positive effect directly on the corporate image is accepted. Based on the analysis result, the $\mathrm{X}_{1}$ (quality of service) variablepath coefficient obtained to variable $Y$ (corporate image) is equal to 0.491 or by $49.1 \%$, with a significance of 0.000 . This means that the better quality of service provided to customers will increase the corporate image.

The results show that the promotion has a significant and positive effect directly on the corporate image is accepted. Based on the analysis result, the $\mathrm{X}_{2}$ (promotion) variablepath coefficient obtained to variable $Y$ (corporate image) is equal to 0.391 or by $39.1 \%$, with a significance of 0.000 . This means that the better the promotional activities carried out then the image of the corporate will increase.

The results show that the quality of service has a significant and positive effect directly on the customer's decision to save is accepted. Based on the analysis result, theX ${ }_{1}$ (quality of service) variablepath coefficient obtained to variable $Z$ (customers decision to save) is equal to 0.316 , or $31.6 \%$, with a significance of 0.000 . This means that the better quality of service, the customer's decision to save will increase.

The results show that the promotionhave a significant and positive effect directly on the customer's decision to save is accepted. Based on the analysis result, theX ${ }_{2}$ (promotion) variablepath coefficient obtained to variable $Z$ (customers decision to save) is equal to 0.279 or $27.9 \%$, with a significance of 0.000 . This means that the better the promotional activities, the customer's decision to save will increase. 
The results show that the corporate image have a significant and positive effect directly on the the customer's decision to save is accepted. Based on the analysis result, the $Y$ (corporate image) variable path coefficient obtained to variable $\mathrm{Z}$ (customers decision to save) is equal to 0.344 , or $34.4 \%$, with a significance of 0.000 . This means that the better the corporate image, the customer's decision to save will increase.

The results show the amount of the positive and significant effectindirectly of service quality on customers' decision to save through the corporate image is accepted. Based on the results of the analysis, $X_{1}$ (service quality) variable path coefficient obtained to variable $Z$ (customer decision to save) through the corporate image is 0.168 or $16.8 \%$.

The results show the amount of the positive and significant effectindirectly of promotion on customers' decision to save through the corporate image is accepted. Based on the results of the analysis, $\mathrm{X}_{2}$ (promotion) variable path coefficient obtained to variable $\mathrm{Z}$ (customer decision to save) through the corporate image is 0.134 or $13.4 \%$.

\section{REFERENCES}

1. Ali, Hasa. (2013). Marketing and Kasus-kasus Pilihan [Marketing and Picked Cases], CAPS (Center for Academic Publishing Service, Yogyakarta.

2. Andi. Gitosudarmo Indriyo. (2012). Manajemen Pemasaran. Edisi kedua, cetakan kedua.Penerbit: BPFE-Yogyakarta.

3. Assauri, Sofjan. (2013). Manajemen Pemasaran [Marketing Management], Rajawali Pers, Jakarta.

4. As'adi. (2009). Cara Pintar Promosi [Smart Campaign], Gerai Ilmu, Yogyakarta.

5. Basu, Swastha. (2009). Manajemen Penjualan [Selling Management]. Penerbit: BPFEYogyakarta.

6. Buchari Alma. (2014). Manajemen Pemasaran \& Pemasaran Jasa [Marketing Management and Marketing Services]. Bandung: CV. Alfabeta.

7. Deli Darlina. (2016). Pengaruh Citra Perusahaan and Kualitas Pelayanan terhadap Loyalitas Pelanggan pada Jas Perhotelan (Kasus Hotel Benteng Pekanbaru) [Influence of Company imageand Quality Serviceon Customer Loyalty on Hospitality services (Case Benteng Hotel Pekanbaru)]. JOM FISIP Journal. Vol. 1, No. 3. Universitas Riau.

8. Deliyanti and Oentoro. (2010). ManajemenPemasaran Modern [Modern Marketing Management]. PT. LaksBangPRESSindo, Jakarta.

9. Dwi Priyatno. (2008).Mandiri Belajar SPSS [Learning Self SPSS]., Mediakom, Yogyakarta

10. Emny Oktavianty Tampubolon. (2015). Pengaruh Promosi Terhadap Citra Perusahaan Pada Hotel Resty Menara Pekanbaru [Effect of Promotion on Company at Resty Menara Hotel Pekanbaru]. Jurnal Jom Fisip Vol. 2, No.2. Universitas Riau.

11. Estri Juwanita. (2015). Pengaruh PersepsiNasabah mengenai Lembaga Penjamin Simpanan (LPS) and Tingkat Suku Bunga Simpanan Terhadap Keputusan Nasabah Menabung pada Bank dengan Citra Perbankan sebagai VariabeIModerasi [The Influence of Customer Perception regarding Deposit Insurance Institutions (LPS) and Deposit Interest Rates on Savings Customer Decisions at Banks with Banking Image as Moderation Variables]. Jurnal Kajian Ilmu Akuntansi (Profita), Vol. 3 No. 3. Universitas Negeri Yogyakarta.

12. Fajar, Laksana. (2008). Manajemen Pemasaran [Marketing Management]. Graha IImu, Yogyakarta.

13. Fandy Tjiptono, and Gregorius Chandra. (2011). Service, Quality and Satisfaction, 3rd ed. Yogyakarta.

14. Herman and darwis. (2012). Manajemen Labaterhadap Nilai Perusahaan denganCorporateGovernance sebagai Pemoderasi [Profit Management to Company Value with Corporate Governance as Moderating]. Jurnal Keuangan danPerbankan, Vol. 16, No. 1.Universitas MerdekaMalang.

15. Juni Novalina Sirait. (2016).Pengaruh Kualitas Pelayanan terhadap Kepuasan Pelanggan padaWaterpark Perum Bumi Sempaja di kota Samarinda [The Influence of Service 
Quality on Customer Satisfaction in the Water Park Perum Bumi Sempaja in the city of Samarinda]. E-Journal Administrasi Bisnis. Vol. 4, No.2. Universitas Mulawarman Samarinda.

16. Kotler, Philip and Gary Armstrong. (2012). Prinsip-prinsip Pemasaran [Principles of Marketing]. Edisi 13,jilid 1. Jakarta: Erlangga.

17. Khamdan Rifa'i. (2015). Pengaruh Promosi and Kualitas Pelayanan terhadap CitraPerusahaan, Kepercayaan Merek, Kepuasan and Loyalitas Pelanggan Studi pada Nasabah PEMERINTAH Syariah di Banyuwangi [Effect of Promotion and Service Quality on Company Image, Brand Trust, Customer Satisfaction and Loyalty Study on Sharia GOVERNMENT Customers in Banyuwangi]. Jurnal FENOMENA, Vol.14, No. 1. Institut Agama Islam Negeri Jember.

18. Kurtz. (2012). Pengantar Bisnis [Introduction to Business]. Jilid 2. Edisi I, (Translated by: Fadrinsyah Anwar, Emil Salim, Kusnedi). Erlangga, Jakarta.

19. Laura Tjokrowibowo. (2013). AnalisisPengaruh Citra Perusahaan and Kualitas Layanan terhadap Kepuasan Pelanggan dalam rangka membangun Minat Transaksi Ulang (Studi PT. Phillip Securities Indonesia cabang Semarang) [Analysis of the Effect of Company Image and Service Quality on Customer Satisfaction in the context of building the Transaction Interest (Study of PT. Phillip Securities Indonesia Semarang branch)]. Jurnal Sains PemasaranIndonesia, Vol. 12, No. 2. Universitas Diponegoro Semarang.

20. Lupiyoadi, Hamdani. (2008). Manajemen Pemasaran Jasa [Services Marketing Management]. Edisi2. Salemba Empat, Jakarta.

21. Luthfy purnanta. (2015). Pengaruh KualitasLayanan terhadap Citra Perusahaan [Effect of Service Quality on Corporate Image], vol. 07 No. 1 April 2015.

22. Mongkaren, Steffi. (2013). Fasilitas and Kualitas Pelayanan Pengaruhnya Terhadap Kepuasan Penguna Jasa Rumah Sakit Advent Manado [AmenitiesAnd Quality Service Effect on User Satisfaction at Advent Hospital Manado].Jurnal EMBA. Vol. 1, No. 4. Universitas Sam Ratulangi Manado.

23. Muhammad Fajar Fahrudin. (2015). Pengaruh Promosi, Lokasi and Kualitas Layanan terhadap Keputusan Pembelian Nasabah Bank Mandiri Surabaya. Journal of Business and Banking [Effect of Promotion, Location and Service Quality on Purchasing Decisions of Bank Mandiri Customers in Surabaya. Journal of Business and Banking] . Vol.5, No. 1. Sekolah Tinggi llmu EkonomiPerbanas Surabaya.

24. Novita Dian Utami. (2015). Pengaruh Kualitas Produk, Pelayanan, Harga and Lokasi terhadap Loyalitas dengan Kepuasan sebagai Variabel Intervening [Effect of Product Quality, Service, Price and Location on Loyalty with Satisfaction as Intervening Variables]. Jurnal IImu and Riset Manajemen Vol.4, No. 5. Sekolah Tinggi IImu Ekonomilndonesia, Surabaya.

25. Ratih Hurriyati. (2008). Bauran Pemasarandan Loyalitas Konsumen [Marketing Mix and Customer Loyalty], Alfabeta, Bandung.

26. Riduwan and Engkos Achmad Kuncoro. (2012). Cara Menggunakan danMemaknai Path Analysis [How to Use and Interpret the Path Analysis]. Alfabeta, Bandung.

27. Rizky Fakhru Muhammad and Yasin Hanifa. (2014). Pengaruh Promosi and HargaTerhadap Minat Beli Perumahan Obama Pt. Nailah Adi Kurnia Sei Mencirim Medan [The Effect of Promotion and Price on Interest in Buying Obama Housing Pt. Nailah Adi Kurnia Sei Send Medan]. Jurnal Manajemen \&Bisnis. Vol. 14, No. 2. Universitas Muhammadiyah Sumatera Utara. 